\title{
Repentance and Rebirth at the End of Life as We Know It
}

\author{
Agustin Martin G. Rodriguez
}

\section{ABSTRACT}

The author discusses the need for repentance and rebirth in the face of global warming. Showing how the current trends on global warming focus on improving technology and making existing systems more efficient, the author argues for the need for a new rationality to emerge that does not follow the trajectory of the dominant western models of civilizationbuilding. The need to repent the ossification of human existence in mass consumption and production and the rebirth of a new way of being involves the engagement of other rationalities in imagining the new world order that global warming demands.

KEYWORDS: Repentance, rebirth, environmental crisis, Scheler, rationality

We face what I understand to be the end of life as we know it. I do not mean the end of the world per se or the end of human life. I don't presume to know that or believe that this literal end of the world is coming. What I mean to say is that human civilization, the way it has been built and has evolved since the industrial revolution and the rise of mass consumerism, is coming to an end. What are the signs of this? Here are some simple facts.

The Intergovernmental Panel on Climate Change has accepted that there is no stopping global warming and it predicts that the earth's temperature will rise by something like $2.5 \%$ by 2050 . Even if we are able to reduce greenhouse gases to those of the year 2000, global temperature will still increase by 0.6 degree Celsius (Dodds 40-42). The worst effects are unpredictable flooding, droughts, the death of coral reefs, increased rates of extinction, reduced water supply, the drying up of rain forests, the melting of glaciers, increased spread 
Agustin Martin G. Rodriguez, "Repentance and Rebirth at the End of Life as We Know It"

of disease, the deaths of hundreds of thousand of people and the displacement of millions more. In order to reduce the effects of global warming we have to cut greenhouse emission gases by 60 to $80 \%$.

On top of this, petroleum is estimated to run out in something between 20 to 75 years. Estimates differ depending on which groups of scientists one speaks to but even British Petroleum's Statistical Review of World Energy, which is quite optimistic, says that the world still has enough "'proven' reserves to provide 40 years of consumption at current rates" (Howden). This is of course disputed but even this most optimistic of estimates would place the end of the age of petroleum in something like 75 years. The end of the age of petroleum spells the end of mass production, mass agriculture, and most of our known forms of transportation. Unless a miraculous replacement fuel is found, then food production as we know it will drop dramatically and many of our economies will be drastically reduced in size.

Worse than the oil crisis is the impending water crisis. We can always find ways to live without oil but who can live without water? However, the United Nations expects the demand for water to outstrip supply by $30 \%$ by 2040 (Interlandi). The next wars, experts in global politics believe, will be fought over clean water supplies. This drastic shortfall in supply is caused only partially by global warming and mostly by pollution and waste.

Finally, we are facing an extinction crisis. Scientists are finding that species are disappearing from the planet at an alarming rate-a rate that has exceeded any species loss in all of earth's history (Wilson, et al.). This is even greater than the extinction of all the dinosaurs or the loss of species caused by any previous climactic change crisis. Respected American scientists claim that

[o]ne quarter of all mammals, including lions, tigers, rhinos, and most primates, could be declared extinct by the end of this century, along with one in eight bird species, and thousands of plant species.(Wilson, et al.)

They add, "In perpetuating this, the Earth's sixth mass extinction, we may ultimately compromise our own ability to survive."

With all these crises, how can we continue to live life as the way we are now? What I mean to ask is how we can continue with mass consumption and 
mass production when these ways of ours threaten the very sustainability of our existence? As it stands, we have re-engineered our planet by the way we live. And the way we have shaped it, our home, has become hostile to many other species and inhospitable for our own survival. Clearly, we cannot continue to live this way; we must bring an end to our life, to civilization, as we know it.

\section{The Turn of Enframing}

What is causing this dire situation? Let us focus our reflection on the extinction crisis. The major reasons for the massive death of other species are the following: habitat loss due to "agriculture, logging, urban development, dredging, damming, mining and drilling"; the introduction of invasive species by humans into habitats; pollution; overexploitation; and, of course, global warming (Wilson, et al.). Except for global warming, we have been causing such havoc as a species since we started migrating out of Africa. Tens of thousands of years ago, hunting and wildfires caused the extinction of large mammals in Australia (Markey) as well as Asia, the Americas and Europe (Dodds 35). But the crisis today is greater than whatever havoc we have caused in former times. Previously, we could kill off one species at a time with our activities. Today, because of the spread and reach of our species, because of the power and massive scale of our technologies, we can destroy tens of thousands of species a year in the tropical forests alone (Dodds 76).

The reason why we human beings are so massively destructive to other species is because there are just too many of us. Scientists have already estimated that we have overshot the world's capacity to sustainably support our existence by 120 percent (Dodds 32) and still we keep on increasing in population by 200,000 people per day (Dodds 12 ). We will need to continue to invade and destroy more habitats at an enormous rate just to keep us fed. And we will need to deprive other species of vital resources as well. Just to illustrate how expensive it is to keep us fed, let us illustrate how much water we use in preparing meals. Each hamburger requires 3,028 litters of water to produce and a full meal requires 5,591 liters of water (Dodds 21). Imagine how much water we consume and pollute just to feed ourselves. Now imagine the hectares of land used to grow the corn that feeds the cows and the hundreds of species that had to give up their habitat for our burgers. Imagine further how much carbon was released in order to process and transport those cows 
and how much waste was produced to package these meals. Because we produce so much waste and require so much material to sustain us, and because there are simply too many of us, we are making the earth inhospitable for our fellow creatures and also for ourselves. And we have needs beyond food. We also clothe ourselves and produce huge quantities of electronics to amuse ourselves and engage in so many forms of consumption that we have literally invaded almost every corner of the land and sea, and affected even the atmosphere just to be able to live what we believe are good human lives. Perhaps if we were to live simpler and there were a lot less of us, then we could sustain our way of living in the world without being too destructive. But there are just so many of us that any way we live causes a significant impact on the world. Just remember how when there were just a few of us and with technologies had minimal effect on the environment we had still had such an impact on large mammals that we caused their extinction. Today we can multiply those species to the tens of thousands. The reason, of course, is not simply because there are so many of us. More significantly, our way of being in the world has a propensity toward mindless consumption. We are blind consumers whose very way of being in the world is oriented toward feeding the self in myriad ways while being unmindful of the effects of our consumption on others. This mindless consumption is supported by technologies that can re-engineer nature from the nano-level up to the level of "earthscapes."

Our technologies today are destructive on a global scale. For instance, modern agricultural practices with their attendant technologies are "loading all our natural ecosystems with detectable levels of toxins" (Dodds 61). In the old days, before the last 50 to 100 years, if we fouled one part of the earth, we fouled one part of the earth. Today, when we foul the nest, "there is nowhere to go to escape these impacts if they are of a great enough magnitude to destabilize of severely hinder the capacity of the Earth to support our current civilization" (Dodds 36). We as a species can mindlessly destroy so much of our sheltering rock that our actions endanger not only ourselves but all our fellow dwellers on this earth. And this is not only because of sheer number: the way that our technologies can be destructive on a massive scale shows us that there is something destructive in our way of being in the world.

Perhaps there is naturally a profound hunger in us and a profound need to accumulate and consume and these are profoundly tied to the need to survive and propagate. In order to attract mates and allies, we need to show ostensive signs of wealth and power. The ability to acquire and consume much is always 
a very clear sign of power and therefore of desirable genetic material. The need to consume much when there is much is also tied to the preservation instinct because early humans did not control their environment as well as we do now and they had to store up on protein and fat in order to survive the lean periods. We also have a deep need to "control physical and biological surroundings to improve survival and comfort" (Dodds 111). Finally, there is also a deep need to belong to a society and be able to effectively function in it. After all, belonging to a society and being a valued member in it is the prime human tool for survival and flourishing. Securing a place in society often demands owning and consuming what this society requires that we own and consume. These are all quite understandable instincts for survival and have ensured the success of our species. However, on top of these instincts we have added an ethos that allows us to be unmindful of things as they presence, as well as technologies that actualize this ethos and that are able to actualize human enframing of the earth.

Martin Heidegger said that our relationship to the world has been altered by the modernist reduction of the world to an object of calculative thought (Discourse on Thinking 50). Whatever openness, whatever organic relationship we have to the world has been reduced to one of Gestell or "enframing," where we do not allow what is presencing to come to presence (46). All that presences is reduced to our calculation of it in relation to our needs and desires. With the modernist attitude toward presencing, nothing is allowed to presence as presence. Rather, all presencing is reduced to what can be abstracted, numeralized, calculated, and schematized so that it can be manipulated, used, and consumed. With the precision of his poetics, Heidegger says that the world is only allowed to presence as "standing reserve"-as that which exists as an object for present or future consumption. The decision to engage the world in this way happened at a particular moment of the history of the West. It is clear to us now that at a moment of our collective history, a particular group of humans decided that it was more beneficial to live as beings that did not have an inherent openness to the presencing of what presences. It began with Descartes' doubt of our capacity to know beyond clear and distinct concepts, deepened with Hume's skepticism regarding the mind's capacity to penetrate the principles of nature, and was sealed with Kant's rejection of our capacity to know the noumena and his insistence that what can be clearly known to reason are phenomena defined by the categories of consciousness. And so today, we act as if we cannot know what is good and true because what pres- 
Agustin Martin G. Rodriguez, "Repentance and Rebirth at the End of Life as We Know It"

ences cannot be known as what presences, and we proceed according only to what works because that is what can be known and determined.

But is it not more beneficial to exist this way? Not to have to wait for the coming to revelation of beings, to be able to believe that the self-revelation of beings is closed to us and remains inaccessible, to be able to accept that all we can know of being is our framing of it according to our categories of understanding and forms of sensibility-all of these allow us to engage reality on our own terms. Doing so cuts the time of waiting for presence to unconceal. It allows the concealed to remain in concealment without this concealment delaying our machinations. This decision to doubt our inherent openness to the real allowed us to push scientific knowledge to new borders. From a desire to faithfully map the cosmos and describe the structure of being, science sought to map out reality according to a precise system of symbols that allows us to understand the world as a mechanism with precise workings that can be manipulated. We decided to open to the real as a totality that could be comprehended as a mechanism. This is where the crucial turn happens: when we begin to view what presences as problem and not as mystery (Marcel 115), when the earth is governed not by spirit but blind drive and impersonal law (Collins), and when we remorselessly focused on finding the meaning of the world and not its truth (Tassi 188-89).As Heidegger says, we had forgotten how to release ourselves unto things, to give ourselves unto the mystery of being (Discourse on Thinking 54).

All of this allowed for the creation of a kind of technology that can treat the earth as an inherently spiritless, meaningless reserve of resources waiting to be accessed by men. The earth only drew meaning and value from what could be made of it and what could be drawn from it. We were interested in knowing it only so far as it was a thing to mine for the riches it would yield. And so the world stopped presencing to us; we thought we could manipulate it for our purposes, even if that meant acting as if nothing else mattered, because nothing else has value beyond what we give it. We created technologies that were focused on bringing about outcomes and goals that we decided were necessary and often bulldozed, railroaded, stripped, eroded, and, denuded the potential truth of what is. And what world has it brought us? It is a world in crisis because one of its best adapted species spoiled the nourishing planet with its mindlessness. 


\section{Fault, Repentance, and Forgiveness}

We can safely say that the ethos of this destructive technology came from one group of the human race, a minority, which decided that the way of living supported by this enframing was the best option possible. In order to allow their ways of life to flourish they embarked on the aggressive imposition of their lifeways on the rest of the world-mainly because they needed to always expand markets and secure the standing reserve. Thus, they involved the rest of us in their mammoth industries and transformed us into captive markets. Look at the map below. This is the map which indicates levels of carbon emission. It indicates which countries are most actively engaged in the forms of economic activity that are pollute heavily, that make high demand on resources, and that are oriented toward expanding consumption. The brown and red parts that can be seen mainly in North America, Europe and Australia indicate which parts of the world decided to live in a way that saw that world as standing reserve. The green and white parts of the map are the sections which either did not successfully integrate into the imposed industrial and market systems or were simply not interested in adapting this alien way of being.

\section{Footprint per capita}

No data

$0,000000000 \cdot 1,0000000000$

$1,000000001 \cdot 2,000000000$

$2,000000001 \cdot 3,0000000000$

$3,000000001 \cdot 4,000000000$

$4,000000001 \cdot 5,000000000$

$5,000000001 \cdot 6,000000000$

$6,000000001 \cdot 7,0000000000$

$7,000000001 \cdot 8,000000000$

$8,000000001 \cdot 9,000000000$

$9,000000001 \cdot 10,000000000$

$10,000000001 \cdot 11,000000000$

$11,0000000001 \cdot 12,000000000$

$12,0000000001 \cdot 13,000000000$

$13,0000000001 \cdot 14,000000000$

$14,0000000001 \cdot 15,000000000$

$15,0000000001 \cdot 16,0000000000$

$16,000000001 \cdot 17,000000000$

$17,0000000001 \cdot 18,0000000000$

$18,000000001 \cdot 19,000000000$

$19,0000000001 \cdot 20,000000000$

$20,000000001 \cdot 21,000000000$

$21,0000000001 \cdot 22,0000000000$

$22,000000001 \cdot 23,000000000$

$23,000000001 \cdot 24,0000000000$

$24,000000001 \cdot 25,000000000$

$25,000000001 \cdot 26,0000000000$

$26,0000000001 \cdot 27,000000000$

$27,0000000001 \cdot 28,0000000000$

$28,0000000001 \cdot 29,000000000$

$29,0000000001 \cdot 30,000000000$

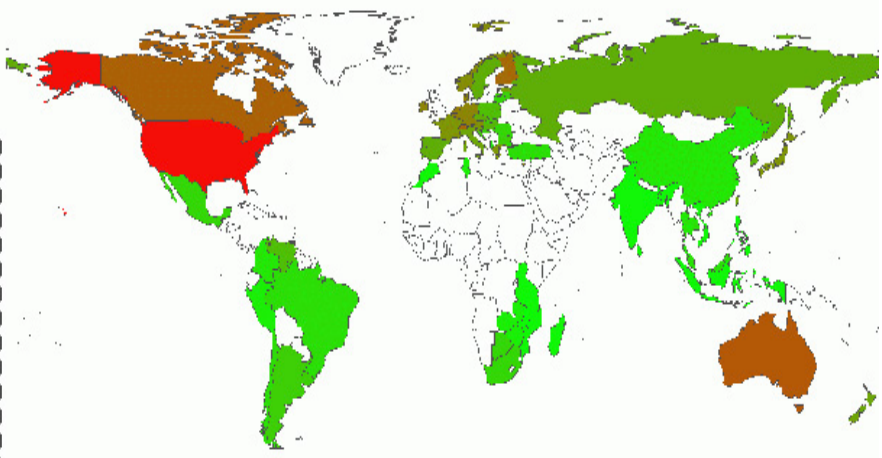

(From http://carbonfootprintofnations.com/content/ranking/) 
Those of us who are still able to talk to and understand the marginalized peoples of our nation realize that they for the most part do not share the values of consumption for consumption's sake, are not comfortable with abstracting their relationship to the earth in order to more efficiently manipulate it, and are unable to depersonalize nature in order to better exploit it. The ambitions of creating technologies and processes that are meant to perpetuate an image of the human as the being which is able to refashion the world into its hostand by host I mean the living being that keeps parasites alive-do not belong to these people in the white and green parts of the world. These nations that are colored red and brown have ravaged the earth and their fellow human beings in order to create an abstract form of wealth, to possess power to control resources, and to continuously produce and innovate to sustain the illusion that human beings have full control of the mechanisms of nature and have the right to demand of it what they desire. As we can see, much of humanity has not bought into that way of being or has been shut out of it. And as you can see, much of those who have created this new world order are concentrated in few parts of the earth. We can fairly say that all human beings have the instinct for consumption and accumulation, for environmental engineering, and securing their material needs for a comfortable existence. However, when the West embraced the capacity for enframing and realized the technologies that supported this, these human instincts and desires became primary causes for mass extinction and environmental degradation on a global scale.

Now take a look at this other map. This map shows us who will pay for this way of being in the world that a minority decided was the best way to live. Again, it is the part of the world that is least actively involved in creating and maintaining the enframing way of being in the world that has caused global warming and its antecedent and precedent crises. It is also the part of the world where many peoples are still attuned to nature's cycles and and practice sustainable processes. These are the parts of the world where there are people who either openly rejected the ways of Gestell because they intuited how their humanity would be adversely affected by it or were refused access to the technologies and systems that would allow them to become active players in the subjugation of the earth. 
Estimated Deaths Attributed to Climate Change in the Year 2000, by Subregion*

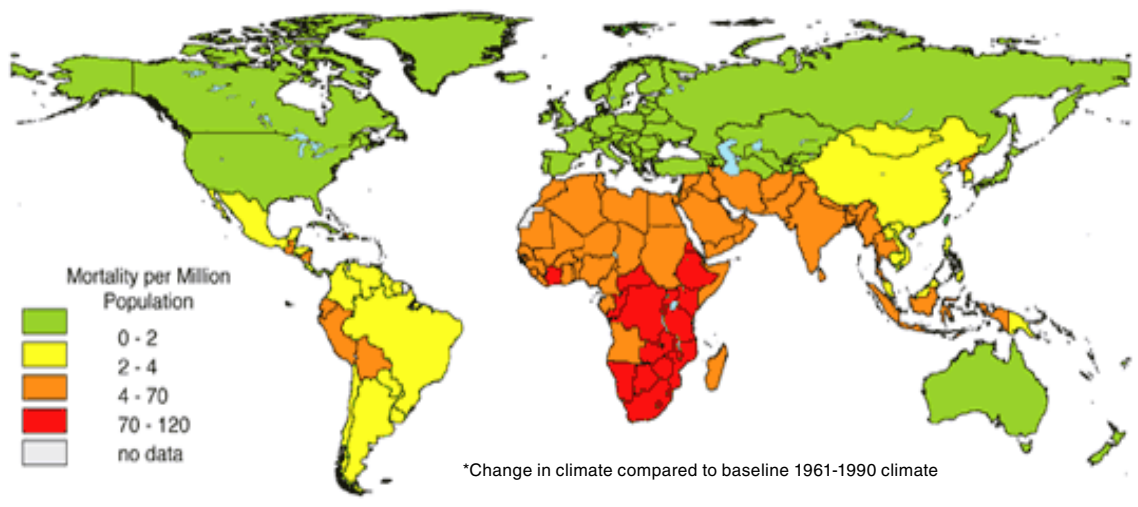

From "Developing Countries To Suffer Worst Global Warming Impacts," by Paroma Basu, University of Wisconsin news release, November 18, 2005, (http://news. mongabay.com/2005/1118-wisc.html)

This brings us to the question of responsibility or fault and the need for repentance. Taking the point of view of the developing world, or the marginalized world, or the world most victimized by western enframing-I have to say that the coming times of great difficulty and death are disturbing not only because of the suffering and tragedy they will bring but because of the injustice of it all. Just looking at these maps tells you all there is to know by way of the injustice. Africa, which has contributed so little to the tragedy of enframing, will suffer most from it. We will suffer moderately but seemingly disproportionately compared to what we have contributed.

Why is it that have we contributed so little to global warming and to the many tragedies that will befall us? Simply because a majority of our people do not use the technologies and systems of production that have contributed much to global warming, or extinction, or to the depletion of resources. Our 
traditional ways are not petroleum-hungry or water-hungry. For instance, one American uses as much energy as 31 Indians, and uses 159 gallons of water a day (compared to 25 gallons per person per day for more than half of the world's people). The map below illustrates the disparity of water usage. These countries that produce the most carbon use up most of the world's resources because they have technologies that are set up to extract so much to produce so much in order to allow them to consume so much. Most of us in the developing world do not have access to such technologies. The question is, why didn't we produce such technologies that would have allowed us to consume and produce as much? I believe it is because it takes a certain ethos to be able to create, develop, and successfully use such technologies. It is an ethos of enframing that we have not developed. The reason why we are so "underdeveloped" is because we cannot embrace this way of relating to the earth.

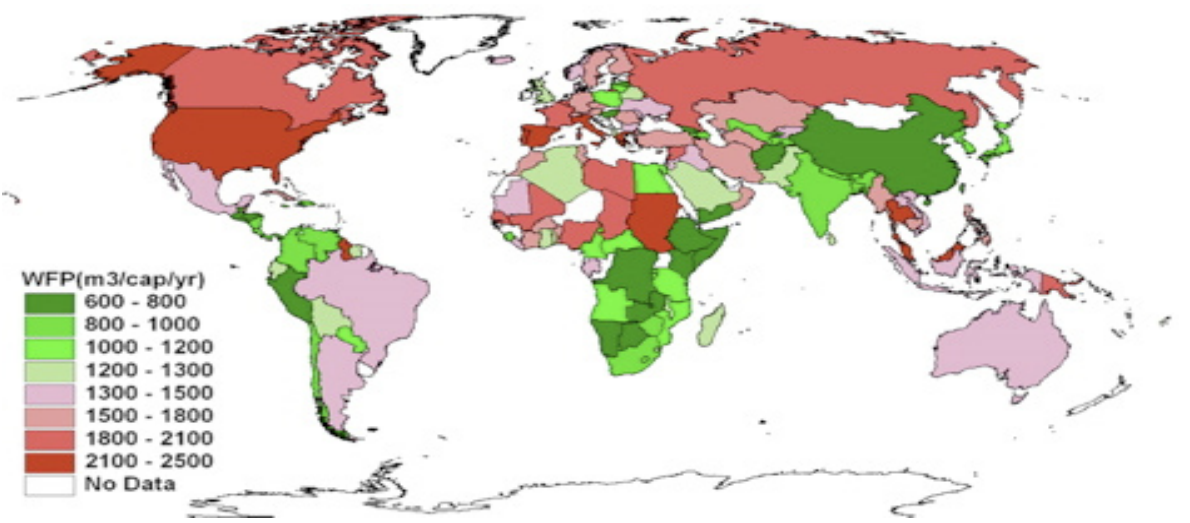

Map Showing Comparative Water Consumption from http://www.treehugger.com/ files/2009/06/we-use-how-much-water.php

The ethos of the majority of our people is oriented toward an openness to what presences without completely abstracting it from its mystery. I do not mean to romanticize the traditional rationalities. However, they are rationalities that have created societies that were sustainable until they were overrun by the destructive enframing of the West. And it seems that they survive-not "thrive," mind you, because they are impoverished by the imposition of the more aggressive dominant rationalities-while making the least impact on the world. They survive on a different ethos than that which exploits the world. 
Today, as we face the end of life as we know it, we cannot help but question the inherent injustice of our situation. So-called developed nations are uncomfortable with questions like these because they imply reparation, responsibility, and reform. Because, if this was a war and one nation was unjustly invaded by another completely without provocation, and the invader caused great suffering and destruction that would last beyond the period of actual invasion, the victims would undoubtedly have a right to reparation. We would be calling this invasion a crime against humanity and would be demanding for immediate cessation of hostilities and for reparation be made to the victims. There is an ongoing crime against humanity that was initiated when the West discovered its capacity to almost completely reduce nature to abstract, mechanical terms. But nothing is happening by way of reparation. No one has successfully brought the developed countries to account for their fault. And the sad truth is, only a few people are calling into account the dominant economic and industrial systems that enframe us. Despite the fact that the world as we know it is coming to an end, we all aspire still to develop like the West and few question this vision of development. This is precisely the condition of fallenness-that unless we repent our false concretizations of our selves, we will always be stuck in our destructive way of being. ${ }^{1}$ And this is why we must struggle hard to name the root of the malady of our times.

I insist on saying that there has been a great injustice that has been committed by the developed world against the developing world. The injustice continues and it must stop. If this injustice, which is rooted in a destructive way of being does not stop, then we will all perish.

\section{Repentance and Rebirth}

In order to break out of our destructive systems which are today the concrete realizations of our human creativity, we must be able to re-imagine our ways of being in the world with others. This will not be possible unless we repent our destructive ways of being. The reductionist systems of enframing are so pervasive that we are all caught in them. Even those who don't agree with their goals and methods are caught in them and believe that the only way

${ }^{1}$ See (Scheler, "Repentance and Rebirth"). I will borrow much of my discussion on repentance and rebirth from Scheler's ideas. 
we can achieve our own salvation from poverty and degradation is to develop like Western countries. This of course is a trap because our movement to becoming like them will only escalate the destruction of our world. And we also have to understand that although it is the developed countries that are taking the lead in bringing us out of this mess, we cannot mainly rely on their methods because they are still caught in the same enframing ethos, the same development models. And unless they are derailed from this, the ongoing development model that they support will surely bring us all to perdition.

This is the reason we must engage in a genuine process of repentance. Genuine repentance breaks the cycle of destructive self-concretization. A person caught in this cycle is one whose realization of self is defined by a false valuation and understanding of one's potential in the world. This false selfconcretization is manifested in the destructive relationship that a person has to the world and to her self. This destructive self-realization is hard to break because the very system of understanding and valuation that shapes her being in this way does not allow her to understand or value things otherwise. Thus, it is hard for the perpetrators of the enframing way of being to realize other possible ways of being and engaging the world. It will take a catastrophe to derail our blind rush to self-annihilation. We should not want to wait for a tragedy to happen to repent and reform our way of being in the world, and so we cannot leave it to the developed countries to set us on another path.

In order to break this obsessive path to self-destruction, we must be able to somehow break the hold of the enframing mind on us. We must somehow be able to transcend these systems of valuation and understanding. Thus, it is important that the discourse of renewal and reform include the voices of those of us who are in the under-developed part of the world. Our underdevelopment does not always mean that we lacked the capacity to creatively engage our world and to flourish. Rather, it often signals the fact that we were able to find ways of engaging the world that are not compatible with, but are susceptible to, enframing. It also signals a rationality that may perhaps have found a balance of living with the earth that allowed for the mutual flourishing of persons and others, a way of being without destroying or excessive exploiting. This is of course not necessarily true, but there is some indication that there are more traditional cultures that are founded on philosophies of sharing and unity, harmony and sustainability. The Ifugao rice terraces were clearly 
created by a people who were fueled by such principles. They worked the terraces communally, grounding earth to sky to spirit, sharing the produce so that people were taken care of. These people shared even the game that they caught. This way, populations grew at a more sustainable rate, marginalization was at a minimum, and people stayed close to the source of their life and spirit. Of course, to an extent, I could be romanticizing the past just as any thinker trained in the humanities tends to do when faced with a crisis that threatens to destroy life as they know it. But we need to know if these cultures did actually live accordingto ways that could save us.

Non-western thinkers who stand at a time when life as we know it is coming to an end are given the task of remembrance or recovery. We who are western trained but also rooted in civilizations that have thrived longer than this one that is bringing us perdition are being called to return to our roots and rethink our people's wisdom, not as romantics, not as foreigners, not as tourists-but as natives who have to rediscover the metis of our people. We are inheritors of a wisdom formed by our civilizations' opening to the presencing of the what comes forth in the earth. There is much about our civilizations" wisdoms that we have to recover in order to re-explore with our fellow human beings a more creative way of dwelling.

For too long, the rationalities of the marginalized have been devalued or were romanticized which effectively rendered them irrelevant. Today we need to bring these rationalities to the global discourse of rebuilding civilization, or else we will rebuild without the benefit of the rationalities that engage the world in ways other than enframing. The global discourse of reform today continues to be a discourse of enframing. They speak of acceptable ways of cutting emissions while sustaining the development models that have been hoisted upon us. They speak of growth by creating less polluting technologies without addressing their unbridled hunger for consumption. They talk of carbon trading and green energy sources without thinking about creating economic systems that are just and fair to all, including nature. Without an other voice that speaks from another rationality, we will remain caught in the ways of the destructive self-realization of contemporary global rationalities. And so we need people to articulate the voices of the marginalized in order for us to awaken to the other possibilities of the prevailing ways of being and be thus given the chance to repent our enframing ways. This is the call to the responsibility of remembrance. 
Agustin Martin G. Rodriguez, "Repentance and Rebirth at the End of Life as We Know It"

How can we proceed without understanding that there are alternatives to our destructive self-concretization? How can we choose to be otherwise when there are no exemplars of other ways of proceeding? This is a time of repentance but it is also a time of rebirth: a time to understand how our being in the world has become destructive, but also a time to articulate other possibilities. With true repentance comes rebirth. Rebirth means the willful breaking away from our self-destructive self-concretization in order to be able to explore and realize other possibilities. Those marginalized by our enframing ways of being should be part of the discourse of rebirth.

Thus, we should not simply forgive and forget, when life as we know it is coming to an end. It is a time of repentance and therefore a time to recognize that we have fallen and to see why that has happened. It is also a time of remembrance. We must remember, rearticulate and bring to the discourse of reconstruction the voices of the marginalized because they have been able to preserve something of the wisdom that allowed us to live with the earth. It is also a time for a rebirth that moves us forward, not just from the destructive ways that we have fashioned but even from the past that seems to stand, so romantically, for a better time. We cannot go back because we have changed so much and the earth has changed so much. Our past ways of living are no longer effective or even possible for the world we created. But by remembering, we can re-imagine the future of the human.

Perhaps, this is an "age of adjustment" like Scheler once thought ("Man in the Era of Adjustment" 110-12). Perhaps we built our civilizations with an over-emphasis on calculative reason, and now it is time to restore the balance to rationalities that can release unto the presencing of what presences. It is a time for balancing thinking as Gestell with thinking as Gelaßenheit. Thus we see the importance of raising voices from the margins through genuine remembering and empowerment. Our rebirth will only come with balance, and this begins with recovery.

Perhaps after this process of recovery and balance, we will discover something important-and that is a second naiveté regarding our being in the world (Ricoeur 352). Our ancestors built a world with a first naïveté-an innocence of building without knowing how terrible our hearts could be, how our primal instincts when pushed to the edge and equipped with immensely powerful tools could bring about such destruction. But now that we have become aware 
of our terrible capacity, we can now recover our possibilities with open eyes. Knowing how destructive and creative we can be, we can build again carefully. Now that we have fallen, can we rise again toward fullness without placing ourselves in the same path to perdition. Hopefully, having been forced to face ourselves, we can embrace the potential darkness of our calculating drives and find a wholeness that is not determined or controlled by it.

Heidegger quotes Hölderlin when he says "But where danger is, grows/ the saving power also" ("The Turning" 42). In this moment of the danger, we are facing an invitation to turn to salvation. The invitation is to build a better society-one where the potentials of human dwelling will be rearticulated more creatively and more rooted in the truth of our being in the world with others. This all begins with repentance and remembrance.

\section{Works Cited}

Collins, James. A History of Modern European Philosophy. Milwaukee: Bruce, 1954. Print.

Dodds, Walter. Humanity's Footprint. New York: Colombia U.P., 2008. Print.

Heidegger, Martin. "The Turning." The Question Concerning Technology and Other Essays.Trans.

William Lovitt. New York: Harper \& Row, 1977. 36-52. Print.

-- . Discourse on Thinking.Trans. John M. Anderson and E. Hans Freund. New York: Harper $\&$ Row, 1966. Print.

Howden, Daniel. "World Oil Supplies Are Set to Run Out Faster than Expected, Warn Scientists." The Independent.Web. 14 June 2007. <http://www.independent.co.uk/news/ science/world-oil-supplies-are-set-to-run-out-faster-than-expected-warn-scientists453068.html>.

Interlandi, Jeneen. "The New Oil: Should Private Companies Control Our Most Precious Natural Resource?" Newsweek.Web. 8 Oct. 2010. <http://www.newsweek. com/2010/10/08/the-race-to-buy-up-the-world-s-water.html>.

Marcel, Gabriel. "Primary and Secondary Reflection."Mystery of Being Vol. 1: Reflection and Mystery. Chicago: Henry Regnery, 1960. Print.

Markey, Sean. "Humans Caused Australia's Ice Age Extinctions, Tooth Study Says."National Geographic News.Web. 24 Jan. 2007. <http://news.nationalgeographic.com/ news/2007/01/070124-iceage-fossils_2.html>.

Ricoeur, Paul. TheSymbolism of Evil. Boston: Beacon Press, 1967. Print.

Scheler, Max. "Man in the Era of Adjustment." Philosophical Perspectives.Trans. Oscar Haac. Boston: Beacon Press, 1958. 110-112. Print. 
Agustin Martin G. Rodriguez, "Repentance and Rebirth at the End of Life as We Know It"

--_. "Repentance and Rebirth."On the Eternal in Man. Trans. Bernard Noble. New York: Harper \& Brothers Publishers, 1960. Print.

Tassi, Aldo. "Modernity as the Transformation of Truth into Meaning."International Philosophical Quarterly 22.3 (1982): 185-193. Print.

Wilson, E.O., et al. "Insights: Human Activities Cause of Current Extinction Crisis." Environment News Service.Web. 19 May 2005. <http://www.ens-newswire.com/ens/ may2005/2005-05-19-insltr.asp>.

Agustin Martin G. Rodriguez is an associate professor at the Ateneo de Manila University and is Chair of the Department of Philosophy. He is also a fellow of the Institute of Philippine Culture and is author of Governing the Other. 